\title{
Cztery podstawowe typy czynności składania świadectwa ${ }^{1}$
}

\author{
Wroctawski Rocznik \\ Historii Mówionej \\ Wydanie specjane, 2018 \\ ISSN 2084-0578 \\ DOI: 10.26774 /wrhm.220
}

Pojęcia „świadek”, „świadectwo” i „składanie świadectwa” przeżywają w ostatnich dekadach dwudziestego stulecia nieustanny rozwój. Znajdują się w centrum uwagi nauki i praktyki kulturowej. Konferencja w Arnoldshain może przyłączyć się do naukowego dyskursu, którego owoc stanowią ważne rozprawy i dzieła zbiorowe z przeróżnych dyscyplin oscylujących wokół tej tematyki ${ }^{2}$. Na gruncie praktyki kulturowej warte wspomnienia

Tłumaczenie za: A. Assmann, Vier Grundtypen von Zeugenschaft, [w:] Im Auftrag der Fritz Bauer Instituts, Zeugenschaft des Holocaust Zwischen Trauma, Tradierung und Ermittlung, red. G. Kossler, Frankfurt 2007, s. 33-51. Zgoda na publikację przetłumaczonej wersji artykułu została udzielona przez Autorkę.

Licencja CC BY-SA 4.0 (przyp. red.).

Testimony. The Crisis of Witnessing in Literature, Psychoanalysis, and History, red. Sh. Felman, D. Laub, New York 1992; Sh. Felman, The Juridical Unconscious: Trials and Traumas in the Twentieth Century, Cambridge 2002; "Niemand zeugt für den Zeugen". Erinnerungskultur und historische Verantwortung nach der Shoah, oprac. U. Beer, Frankfurt a.M. 20oo; G. Hartman, Survivor Testimony: Challenge and Limits, „International Journal: Studies on the Audio-Visual Testimony of Victims of the Nazi Crimes and Genocides" (1999), nr 3, s. 169-173; oraz zeszyt tematyczny Testimony czasopisma „Poetics Today. International Journal for Theory and Analysis of Literature and Communication", t. 27 (2006), nr 2. 
są dwie inicjatywy: archiwum Fortunoff Uniwersytetu Yale gromadzące ok. 15 tys. świadectw w formie nagrań wideo, utworzone w latach 8o. XX w., oraz archiwum Fundacji Shoah założone przez Stevena Spielberga, zawierające ponad 50 tys. nagrań wideo. Oba archiwa tworzą i gromadzą świadectwa ocalałych z Holokaustu, co wskazuje na wyraźny związek między świadectwem a Holokaustem i pokazuje, jak silne jest to powiązanie. Ta konotacja kształtuje nie tylko nasze zainteresowanie czynnością składania świadectwa, lecz także związane $\mathrm{z}$ tym pojęcia. To w żadnym razie nie oznacza, że w dzisiejszych czasach aktualność czynności składania świadectwa ogranicza się do tego historycznego związku. Wprost przeciwnie, paradygmatyczny związek aktu składania świadectwa i Holokaustu przez analogię wprowadził wiele nowych możliwości zastosowań. Stosowanie pojęć związanych z Holokaustem do innych traumatycznych doświadczeń z historii zapewnia im medialną uwagę i polityczne bądź etyczne uznanie. Przykładem tego są słowa Tulli Pokriefke, która przeżyła katastrofę statku „Wilhelm Gustloff”, bezowocnie powtarzane do syna Paula w noweli Güntera Grassa Idac rakiem (2002): „Das mußte aufschraiben. Bist ons schuldig als glicklich Ieberlebender. [...] Ech leb nur noch dafier, dass main Sohn aines Tages mecht Zeugnis ablegen"”. Zamiar zwrócenia uwagi i przeniesienia innych historycznych traum do pamięci kulturowej, nie powoduje, że Holokaust zostaje zapomniany czy wręcz „wyparty”, lecz przyczynia się do "rozszerzenia” pamięci kulturowej. Zresztą Holokaust stał się paradygmatem czynności składania świadectwa, na którym mogą się opierać inne świadectwa w innych kontekstach społecznych, politycznych i kulturowych.

W kontekście aktualnego uwydatnienia tych zagadnień sens może mieć kolejne nieznaczne rozszerzenie kwestii znajdujących się w ich centrum, nie tyle poprzez uznanie alternatywnych form składania świadectwa, ile poprzez historyczną analizę pojęć, a nawet związanych z nimi instytucji. Pojęcie „świadczenia” ma długą historię i bardzo różnorodne cechy dla różnych instytucji kulturalnych. Pamięć, jak wiemy od Maurice’a Halbwachsa, $\mathrm{w}$ żadnym razie nie jest sprawą czysto subiektywną lub wewnętrzną, lecz zawsze wymaga obecności potencjalnych adresatów, a także społecznych instancji potwierdzenia, oceny, uzupełnienia lub korekty wspomnienia. To

G. Grass, Im Krebsgang, Göttingen 2002, s. 31, 19. [„To należy spisać. Jesteś nam to winien jako szczęśliwy ocalały. [...] Żyję tylko po to, aby mój syn pewnego dnia mógł złożyć świadectwo" - przyp. tłum.]. 
nie dotyczy jeszcze w równej mierze czynności świadczenia, która zasad-

niczo jest skierowana na zewnątrz i koncentruje się na adresacie. W tym wypadku w ogóle dopiero adresat sprawia, że wspomnienie staje się świadectwem. Tak jak samo wspomnienie, również świadczenie wymaga określonych - jak to nazwał Halbwachs - „ram”, decydujących o tym, co i w jaki sposób należy wyrazić słowami w odniesieniu do określonej sytuacji z przeszłości. Te sytuacje w kontekście świadczenia przyjmują instytucjonalne formy. Jeszcze bardziej niż w wypadku wspomnienia, podczas czynności składania świadectwa mamy do czynienia z aktem performatywnym, włączonym w specyficzne kulturowe warunki ramowe, które z góry ustalają określone "skrypty” dla ról podczas tych interakcji, a także decydują o doborze tego, co zostanie wyrażone słowami, i o sposobie, w jaki to ma być dokonane i zinterpretowane.

W dalszej części zostaną bliżej zbadane cztery ramy świadczenia. W tym celu konieczne jest przejście z teraźniejszości do historii i odszukanie śladów praktyk, które częściowo zostały zaniechane lub wyszły z użycia. Dlatego też moje studium przyjmie formę zwiedzania, prowadzącego nas przez wyimaginowane muzeum kulturowo-historyczne. Celem tej wycieczki jest jednak nie tylko zaspokojenie historycznej ciekawości; okaże się, że identyfikacja ważnych aspektów obecnych praktyk świadczenia oraz zrozumienie wymiaru historycznego może nastąpić dopiero na rozszerzonej bazie źródłowej. Przedstawione zostaną tutaj cztery podstawowe typy świadków: świadek jurydyczny, świadek religijny, świadek historii i świadek moralny. Te podstawowe formy należy rozumieć jako typy idealne według teorii Maxa Webera: stanowią one abstrakcyjne uogólnienie historycznych przypadków. Nie chodzi mi tu jednak o heurezę porządku i interpretacji historycznej różnorodności, lecz bardziej o rekonstrukcję instytucjonalnych ram, w których zachodzą czynności świadczenia. Na podstawie takiej analizy będzie możliwe zidentyfikowanie i zbadanie także form przejściowych i mieszanych.

\section{1. Świadek jurydyczny}

Na gruncie prawa świadek (łac. testis) ma długą tradycję. Jego funkcje w procesie karnym i cywilnym różnią się od siebie. W procesie karnym ofiara sama występuje w roli świadka, podczas gdy w procesie cywilnym świadek, jako osoba trzecia, wchodzi pomiędzy sprawcę szkody a poszkodowanego. Idealną sytuacją jest, jeżeli w ostatnim przypadku świadek wnosi do procesu bezstronną perspektywę z zewnątrz, która jest gwarancją 
neutralności i obiektywności. Świadek jako osoba trzecia może także poza postępowaniem sądowym uzupełniać diadę złożoną z dwóch stron umowy (mowa na przykład o „świadkach” podczas zawarcia związku małżeńskiego) lub transakcji. W takiej sytuacji osoba trzecia - jako obserwator lub niezależna instancja - jest gwarantem legalności umowy lub procedury. Lingwista Émile Benveniste wskazał na ciekawy językowy związek między figurą „świadka” a figurą „osoby trzeciej”: „posługując się językiem etymologii, testis to ktoś, kto jako osoba trzecia (terstis) uczestniczy w transakcji, która dotyczy dwóch osób"

W procesie sądowym świadek nie mówi w swoim imieniu, lecz przyjmuje powierzoną mu rolę w sterowanym odgórnie procesie poszukiwania i odkrywania prawdy. To, co ma do powiedzenia oraz w jaki sposób ma mówić, stanowi część bardzo sformalizowanej procedury, w której świadectwo pełni funkcję ewidencyjną i dowodu w procesie wydawania wyroku. Zeznanie świadka jest określone surową formą „przesłuchania” lub „wysłuchania”, przy czym świadectwo ogranicza się do wypowiedzi, które przez instancje sądowe są uznawane jako istotne w szerszym kontekście argumentacji lub przeprowadzenia dowodu. Schemat zadawania pytań ma formę interakcji, ale nie dialogu; pod względem nierównego podziału na pytania i odpowiedzi jest zbliżony bardziej do przesłuchania lub egzaminu. Także w sytuacji, w której ofiara przemawia we własnej sprawie, nie może sama określać formy przekazywania informacji, lecz musi odpowiadać na precyzyjne pytania w ustalonej kolejności. W centrum zawsze znajduje się samo postępowanie, nie jednostka ${ }^{5}$. W dalszej części powrócimy jeszcze do tematu dysonansu między stanem psychicznym ofiary naznaczonej traumą a chłodnym procesem prawnym, nastawionym na czysto empiryczne poszukiwanie prawdy.

Wymaganiem procesu jest to, że świadek naoczny lub nauszny, który był obecny na miejscu popełnienia przestępstwa lub wypadku, ma fizyczne i zmysłowe pojęcie o zdarzeniu i jest w stanie później wnieść je do dochodzenia. Tak skonstruowana czynność świadczenia i jej prawna sceneria spełnia cztery ważne warunki i założenia:

Cyt. za: J. Derrida, „A Self-Unsealing Poetic Text” - Poetics and Politics of Witnessing, [w:] Revenge of the Aesthetic, red. M. Clark, Berkeley 20oo, s. 186.

Jako przykład nieodpowiedniego doboru zestawu pytań sędziego do doświadczeń świadka, który przeżył traumę, por. Protokół sądowy przedrukowany w suplemencie w A. Lasker-Wallfisch, Ihr sollt die Wahrheit erben. Breslau - Auschwitz - Bergen - Belsen, Bonn 1997. 
- bezstronności świadka,

- jego bezpośredniego zmysłowego doświadczenia na miejscu zdarzenia,

- jego kompetencji: przechowywania dokładnie zapamiętanego doświadczenia w pamięci aż do momentu jego wywołania,

- jego wiarygodności: dzięki zeznaniom złożonym pod przysięgą wyklucza się zamierzone oszustwo.

Dzięki temu problem prawdy w ramach postępowania prawnego jest pragmatycznie jasno ograniczony, a pytanie o trafność świadectwa (w znaczeniu accuracy) jest ściśle związane $\mathrm{z}$ pytaniem o jego wiarygodność (w znaczeniu sincerity).

\section{2. Świadek religijny}

Podczas gdy łacińskie słowo testis na określenie świadka ukazuje kontekst prawny, greckie słowo martys wskazuje na kontekst religijny. W przypadku męczennika mamy do czynienia z ofiarą, która jest pozbawiona możliwości, aby jej świadectwo zostało wysłuchane przed ziemskim sądem. Sedno sprawy tkwi w tym, że w takim wypadku akt przemocy nie wychodzi od pojedynczego człowieka, a państwo jest adwokatem przywrócenia ładu, lecz samo państwo jest źródłem tego aktu przemocy, co wyklucza ziemskie instancje apelacyjne. Męczennik jest ofiarą politycznego aktu przemocy, któremu ulega; ale nie czyni tego bez apelacji do wyższej instancji religijnej, aby w ten sposób dokonała się konwersja śmierci fizycznej w akt symboliczny. Tym samym „umieranie na” staje się „umieraniem za”. Performatywne przesłanie, jakie zostaje wypowiedziane aktem umierania, jest wyznaniem wiary w najwyższego Boga. W akcie tego wyznania bezbronna pasywność i niechętna ofiara (w znaczeniu łac. victima) zostaje przemieniona w wyższy, aktywny i ochoczy podmiot/obiekt czynności ofiarnej (w znaczeniu sacrificium). Ta radykalna inwersja politycznej niższości w religijną wyższość, traumy w triumf, jest sprawą ram kulturowych, w których to zdarzenie jest przeżywane, interpretowane i oceniane.

W związku z tym, że męczennik umiera ze świadectwem na swych ustach (żydowską formułą śmierci męczeńskiej jest kiddush ha-shem, „uświęcenie Imienia Bożego"), to wyznanie przebrzmiewa wraz z jego śmiercią i nie ma gwarancji, że ten akt zyska długotrwałe znaczenie na ziemi i będzie nadal trwał w przyszłości. Dlatego też świadek-męczennik potrzebuje drugiego świadka naocznego, który dostrzeże jego śmierć, uzna go za ofiarę (sacrificium) i przekaże to dalej w formie poważnego świadectwa. Tak więc w kontekście religijnym składanie świadectwa wyraża się w dwojaki sposób 
w dwóch aktach: w akcie wyznania oraz poświadczenia wyznania. Pierwotne znaczenie słowa martyrium to „relacja świadka o ofiarnej śmierci człowieka”. Zatem martyrium rodzi się nie tylko z samej nagłej śmierci, lecz dopiero z relacji o tej śmierci. W relacji chwila największego poniżenia i zniszczenia w postaci śmierci fizycznej dokonuje się jako performatywny akt składania świadectwa nie tylko realizowany wewnętrznie, lecz także interpretowany na zewnątrz, a tym samym zostaje przemieniona w („nadzwyczajne”) świadectwo, sięgające daleko poza tę śmierć. Tak więc świadectwo jest tym, co trwa dłużej niż męczennik i niweczy zwycięstwo prześladowcy. W takiej pozycji wtórnego świadka stoją ewangeliści opisujący męczeńską śmierć Chrystusa, stoi też Kościół katolicki wobec prześladowanych i zamordowanych Świętych, których kanonizował jako męczenników. Tacy wtórni świadkowie w żadnym wypadku nie są tylko epifenomenem męczeństwa; są tymi, którzy kodują religijne przesłanie, nadając mu formę uzasadniającej historii, na której opierają się wspólnoty wierzących.

Moment czynności składania świadectwa przez naocznego świadka jest wciąż uwydatniany przez ewangelistów. To, co opisują jest poświadczone własną obserwacją, własnymi zmysłami. W Ewangelii wg św. Jana (J 21, 24) ${ }^{8}$ jest napisane: „Ten właśnie uczeń daje świadectwo o tych sprawach, i on je opisał. A wiemy, że świadectwo jego jest prawdziwe". Jan jest także tym uczniem, który był obecny w czasie ukrzyżowania: „Zaświadczył to ten, który widział, a świadectwo jego jest prawdziwe" (J 19, 35). W ikonografii chrześcijańskiej Jan jest przedstawiany jako świadek poprzez gest „pokazywania”. Przykładowo na obrazie ołtarzowym Matthiasa Grünewalda, który ilustruje ukrzyżowanie Chrystusa, uczeń Jan jest ukazany z wyprostowanym palcem wskazującym, skierowanym na Ukrzyżowanego. „Świadczenie" i „pokazywanie” stoją tutaj blisko siebie.

H. Quecke, Ich habe nichts hinzugefügt und nichts weggenommen. Zur Wahrheitsbeteuerung koptischer Martyrien, [w:] Fragen an die altägyptische Literatur. Studien zum Gedenken an Eberhard Otto, red. J. Assmann [et al.], Wiesbaden 1977, s. 3994.16.

Słowo „nadzwyczajnie” wyjaśnił Benveniste w następujący sposób: „Superstes describes the «witness» either as the one who «subsists beyond», witness at the same time as survivor, or as «the one who holds himself to the thing», who is present there"; cyt. za: J. Derrida, op. cit., s. 187.

Tłumaczenie cytatów biblijnych za: Biblia Tysiaclecia, wyd. III poprawione, Poznań-Warszawa 1990 (przyp. red.). 
Kościół katolicki w kontekście beatyfikacji, np. Bernharda Lichtenberga czy Edyty Stein, mówi także o „świadkach wiary”. Naziści tłumaczyli słowo „męczennik” jako „świadek krwi”, jednocześnie przekładając je na sakralny kontekst swojego politycznego kultu zmarłych. Jako świadkowie krwi wspominani byli tzw. bohaterowie ruchu, którzy wraz z Hitlerem byli uczestnikami marszu na Feldherrnhalle w Monachium i ponieśli śmierć podczas puczu w $1923 \mathrm{r}^{10}$ Polityczny wariant świadka religijnego w dzisiejszych czasach zyskał nowe znaczenie w postaci zamachowca samobójcy. To, co w zachodnich kategoriach jest określane jako „samobójstwo”, w islamie stanowi „śmierć męczeńską”. W tej formie męczeństwa nowością jest jednak to, że męczennik staje się bronią, która innych ludzi porywa ku śmierci. W przeciwieństwie do typowego zamachowca, koncentrującego się na wybitnych osobistościach, jak np. szefowie państw, ofiarą zamachowca samobójcy jest jak największa „masa anonimowych osób”. W takiej formie zamachu liczy się przy tym rozgłos medialny, dzięki któremu globalna opinia publiczna wbrew swojej woli staje się przerażonym świadkiem. Takie medialne świadectwo jest ważną częścią samego zamachu, którego istotą jest rozsiewanie nieustannego strachu i przerażenia, także wśród tych, którzy nie są nim bezpośrednio dotknięci ${ }^{11}$.

\section{3. Świadek historii}

Hasła, takie jak „media” oraz „opinia publiczna”, prowadzą nas do trzeciego typu świadka - świadka historii. Jednym z jego poprzedników jest posłaniec odpowiedzialny za relacjonowanie istotnych wydarzeń w świecie, w którym nie ma gazet, reporterów, zdjęć i kanałów informacyjnych. Znamy go z antycznych i klasycznych tragedii, gdzie występuje jako postać przekazująca wiadomość o rozstrzygającym się zdarzeniu. Ta postać zmniejsza dystans między miejscem aktu przemocy lub wojny a tym, co dzieje się na scenie. Jest brakującym ogniwem łączącym miejsce katastrofy z oddalonym w przestrzeni i czasie niewiedzącym. Ten posłaniec jest naocznym świadkiem, często jedynym („nadzwyczajnie”) ocalałym po to, aby przekazać wiadomość. Jako jedyny ocalały ma obowiązek zdania relacji

Zeugen für Christus. Das deutsche Martyriologium des 20. Jahrhunderts, Paderborn, red. H. Moll, München 1999.

S. Behrenbeck, Der Kult um die toten Helden. Nationalsozialistische Mythen, Riten und Symbole 1923 bis 1945, Vierow 1996.

R. Pape, Dying to Win. The Strategic Logic of Suicide Terrorism, New York 2005. 
182 przyszłym pokoleniom, przy czym fakt ocalenia oraz konieczność zdania relacji najczęściej pozostają w ścisłym związku². Istotą antycznej instytucji posłańca nie jest jednak czynność złożenia świadectwa przez naocznego świadka, lecz umiejętność wiarygodnego zapamiętania. W związku z tym, że ta umiejętność zawsze była podawana w wątpliwość, świadectwo posłańca zawierało odpowiednie poświadczenie prawdy, potwierdzenie wiarygodności jego wypowiedzi. Stereotypowa formuła potwierdzenia brzmi: nic nie dodałem, nic nie ująłem i niczego nie przeinaczyłem ${ }^{13}$. Świadectwo złożone przez świadka nie jest zatem zwykłą informacją, lecz, mówiąc językiem teorii aktów mowy, zawsze poświadczoną, autoryzowaną wypowiedzią.

Świadek historii jest jednak nie tylko osobą ocalałą, lecz także Jeszcze Żyjącym, który poprzez swoje doświadczenie i wspomnienie przekazuje kolejnym pokoleniom żywe świadectwo ważnych wydarzeń z przeszłości. Tak jak świadectwo świadka jurydycznego przed sądem przyczynia się do przeprowadzenia dowodu przez sędziego, tak też świadectwo świadka historycznego przyczynia się do rekonstrukcji zdarzeń przez dziejopisarzy. Mimo to i w związku z tym, że spisywanie dziejów nie może obyć się bez świadka historii, jego status pozostaje kontrowersyjny, głównie dla profesjonalnej historiografii ${ }^{14}$.

Świadkami historii moglibyśmy nazwać też fotoreporterów i dziennikarzy naszej epoki mediów, którzy również w niebezpiecznych okolicznościach przenoszą do globalnych kanałów informacyjnych relacje z obszarów objętych wojnami. Świadkowie historii różnią się od zwykłych reporterów tym, że z miejsc, gdzie rozgrywa się niesprawiedliwość i przemoc przesyłają nie tylko informacje, lecz także wiadomości o charakterze szczególnego przekazu. Tacy świadkowie historii nie są bezstronnymi obserwatorami, lecz zaangażowanymi widzami, stojącymi po stronie cierpiących, tak jak wietnamski fotoreporter „Nick” Ut czy amerykański fotograf James Nachtwey. Swoje świadectwo kierują do światowej opinii

Zob. przyp. 7 .

Por. H. Quecke, op. cit. O formułach poświadczających stosowanych później przez kopistów, zob. A. Assmann, Fiktion als Differenz, „Poetica”, 21, 1989, s. 239-26o.

P. Burke, Eyewitnessing. The Uses of Images as Historical Evidence, Ithaca 2001; J. Fried, Der Schleier der Erinnerung, München 2004. Analogie pomiędzy sędzią a historykiem zostały opisane przez Carlo Ginzburga w: idem, Der Richter und der Historiker. Überlegungen zum Fall Sofri, Berlin 1991. 
publicznej, za pomocą zdjęć i relacji, zwracając uwagę na konkretne przypadki nieszczęścia, biedy, bezprawia i przemocy.

Kolejną formą, w jakiej objawia się świadek historii, jest w końcu „żyjący świadek", który uzyskał kluczowe znaczenie w ramach badań historii mówionej. Impulsem tego nowego międzynarodowego kierunku badań, który ukształtował się w latach 6o. XX w. jako gałąź „historii współczesnej", zmierza ku wzbogaceniu naszej wiedzy o wydarzeniach historycznych o wymiar doświadczeń, jednocześnie wprowadzając do historiografii także wymiar "historii oddolnej”15. Wielu historyków wyznaje zasadę uznawania za źródło jedynie „współczesne świadectwo”. Świadectwa dotyczące Holokaustu, złożone przed 1946 r., są klasyfikowane inaczej, niż świadectwa spisane 50 lat po wydarzeniach. Żyjący świadek, jak to określił Grass, jest „wymierającym gatunkiem”. To, że śmierć starszego pokolenia, będąca sama w sobie najbardziej oczywistą rzeczą na świecie, w ogóle stała się współczesnym tematem, jest związane z przełomowymi wydarzeniami II wojny światowej i Holokaustu oraz ze szczególną rolą tego starszego pokolenia, jako świadka. Żyjący świadkowie są ostatnim obecnym wśród nas ogniwem łączącym nasze czasy z okresem dyktatury nazistowskiej. Terminologiczna zamiana „sprawców” na „żyjących świadków”, dająca się zaobserwować od około dziesięciolecia, wskazuje na rosnący dystans do epoki zbrodni i jej historyzacji. A to dlatego, że żyjący świadkowie zaświadczają o wszystkim, co możliwe, oprócz własnych zbrodni. W tematyce Holokaustu nie ma prawie w ogóle (dobrowolnych) „świadectw sprawców”, o wiele więcej mamy świadectw ofiar. Te świadectwa z kolei stanowią historyczne novum i dlatego wymagają wprowadzenia "nowego” typu, mianowicie „świadka moralnego".

\section{4. Świadek moralny}

W konsekwencji Holokaustu, u schyłku XX w. świadek znalazł się w centrum uwagi, manifestując się w nowej odsłonie. Określę go mianem świadka „moralnego”, stworzonym przez izraelskiego filozofa Avishai Margalita. Przedstawił on ten typ w jednym z rozdziałów swojej książki The Ethics of Memory, opisując jego wyjątkowość na przykładzie osób, które przeżyły

Lebenserfahrung und kollektives Gedächtnis. Die Praxis der „Oral History”, red. L. Niethammer, Frankfurt a.M. 1985. 
184 Holokaust ${ }^{16}$. W związku z tym, że ten nowy typ przejął cechy wszystkich innych świadków, a jednocześnie fundamentalnie różni się od nich wszystkich, naszkicowanie, przynajmniej teoretyczne, zróżnicowanej „typologii świadka" było tutaj konieczne.

Dla świadka religijnego i świadka moralnego wspólne jest to, że łączą w sobie rolę ofiary i świadka. Jednakże tym, co odróżnia świadka moralnego od męczennika jest to, że staje się on świadkiem nie poprzez swoje „umieranie”, lecz dzięki temu, że „przeżył”. Jako osoba, która przeżyła („nadzwyczajnie"), staje się z kolei przede wszystkim rzecznikiem i świadkiem tych, którzy nie przeżyli; staje się rzecznikiem zamordowanych i przypomnieniem ich wymazanych z pamięci nazwisk. Dlatego też, jak zwróciła uwagę Sigrid Weigel, świadectwo świadka moralnego stoi nie (tylko) pod znakiem „oskarżenia”, jak świadectwo świadka jurydycznego, lecz także jest „skargą umarłych”. Skarga jako forma świadectwa ma niewiele wspólnego z buchalteryjną skrupulatnością świadectwa wymaganego prawem i zawiera w sobie również właśnie milczenie jako prawo do niemówienia ${ }^{17}$. Drugą, nie mniej istotną różnicą w porównaniu ze świadkiem religijnym, jest to, że świadek moralny poświadcza nie tyle pozytywne przesłanie, ile moc najwyższego Boga, za którego warto umrzeć. W absolutnym przeciwieństwie do takiej uświęcającej semantyki zostaje ujawniona kolosalna zbrodnia i otwarcie złożone świadectwo o obecności zła doświadczonego bezpośrednio na własnej skórze, w formie zorganizowanego aktu bestialskiej przemocy. Celem negatywnego przekazu nie jest nadanie sensu, czy stworzenie historii, na bazie której zakłada się wspólnoty. Z tego punktu widzenia takie świadectwo nie tworzy wspomnienia „użytecznego” dla ogółu. (To jednak nie oznacza, że takie świadectwo nie może być przekształcone w narrację, która jest politycznie motywująca i dosięga aspektów państwowych).

Tak jak świadek religijny, także świadek moralny jest zdany na obecność świadka wtórnego, który przyjmie jego przekaz. Primo Levi już w Auschwitz śnił koszmary, że w końcu powrócił do domu, lecz tam nikt nie chciał słuchać jego historii. Bez przyjęcia przesłania świadka moralnego, jego ocalenie, z którym wiązał się absolutny obowiązek złożenia świadectwa, stałoby się bezsensowne.

A. Margalit, The Ethics of Memory, Cambridge 2002, s. 147-182.

S. Weigel, Zeugnis und Zeugenschaft, Klage und Anklage, [w:] Zeugnis und Zeugenschaft, Jahrbuch des Einsteinforum, Berlin 1999, s. 120-123. 
„Nikt

nie zaświadczy

za świadka"

to słowa z wiersza Aschenglorie Paula Celana ${ }^{18}$. W 1967 r., kiedy ukazał się ten tom poezji, karty zaczęły się odwracać - zbierała się wspólnota coraz bardziej zaintrygowana wtórnymi świadkami, która rozpoczęła zbieranie świadectw ocalałych. Podczas gdy jeszcze na początku lat 6o. świadectwa z wielkich procesów w sprawie Holokaustu w Jerozolimie (1961 r.) i Frankfurcie (1964 r.) były jeszcze całkowicie wpasowane w surowy format sądowego przestuchania, stopniowo tworzyło się środowisko społecznego zainteresowania, które dało ocalałym prawo do bycia wystuchanym przez ludzi także poza ramami instytucji. Bernhard Giesen w swoim studium Triumph and Trauma w sposób przekonujący przedstawia ten nieunikniony związek między świadkiem pierwotnym a wtórnym, między ofiarą przeżywającą traumę a wspólnotą moralną. W chwili prześladowania, poniżenia i mordu ofiary doświadczające traumy nie mają twarzy, głosu, miejsca, historii. Dopiero uniwersalistyczna wspólnota stojąca poza diadą sprawca-ofiara, składająca się z "osób trzecich” (terstes), które nie zostały dotknięte wydarzeniami, przysłuchuje się świadectwu tych świadków, nadając im status ofiary ${ }^{19}$. Tym samym z „ofiary”, będącej konsekwencją wiktymizującego aktu przemocy, powstaje „ofiara”, będąca społeczną konstrukcją wspólnoty moralnej i jej publicznej perspektywy. Wspólnota moralna, która na bazie wartości cywilnospołecznych dystansuje się od wiktymizującego aktu przemocy, tendencyjnie obejmuje całą ludzkość, gdyż jest stworzona na fundamencie uniwersalistycznych wartości godności ludzkiej i szacunku dla fizycznej integralności bliźnich. Jako inkluzywna uniwersalistyczna wspólnota opiera się jednocześnie na publicznej i nieograniczonej arenie dyskursu, a tym samym stoi w opozycji do grup ekskluzywnych, kreślących wyraźne granice tożsamości, zaakcentowane przez kryteria przynależności. Za pomocą funkcji definiowania porządku moralnego i podkreślania winy i odpowiedzialności dyskurs ten przyjmuje pewne warunki systemu prawnego, które uogólnia, przenosząc

P. Celan, Atemwende, Frankfurt a.M. 1967, s. 68.

B. Giesen, Triumph and Trauma, London 2004, s. 51. Nie mogę podążać jednak za Giesenem w jego uogólnieniu traumatycznego pojęcia ofiary jako wytworu bezosobowego i anonimowego współczesnego społeczeństwa masowego; ibidem, s. 51, 53, 65. 
do społeczeństwa. Nie konkurując z systemem prawnym, ten uniwersalistyczny dyskurs bierze pod uwagę gwałtowność i rozmiar zbrodni, którą przepracowuje się bardzo fragmentarycznie i niedoskonale $\mathrm{w}$ formie postępowania karnego ${ }^{20}$. W taki sposób akt składania wtórnego świadectwa zostaje przyjęty przez społeczeństwo, które następnie przepracowuje traumatyczną przeszłość, posługując się formami odpowiedzialności politycznej i kultury pamięci, stawiającej w centrum empatię i solidarność z ofiarami.

W tym nowym typie „świadka moralnego” Margalit wyróżnił trzy szczególnie ważne aspekty: ucieleśnioną prawdziwość świadectwa, konstrukcję moralnej instancji oraz misję prawdy. Najpierw zajmijmy się aspektem ucieleśnionej prawdziwości: Margalit starannie odróżnia świadka moralnego od neutralnego i obojętnego obserwatora, który jest charakterystyczny dla typu świadka jurydycznego i świadka historii. Według Margalita sprawą absolutnie decydującą dla świadka moralnego jest unia personalna ofiary i świadka: zbrodnię, o której zaświadczają, oboje przeżyli na własnej skórze. W związku z tym, że pozostając bez ochrony byli bezpośrednio wystawieni na przemoc, wpisała się ona w ich ciała i dusze. Tym samym ciało pozostaje miejscem, w którym rozgrywa się traumatyzująca przemoc, a wraz z nią jednocześnie "pamięć" tego świadka, której nie da się tak łatwo pozbyć, jak wiadomości, którą ma do przekazania posłaniec. Świadek moralny nie jest naczyniem, w którym można umieścić wiadomość - naczyniem jest tutaj sama wiadomość. Jednocześnie w nowym świetle stawiane jest pytanie o prawdziwość świadectwa: niemożliwe jest potwierdzenie go przysięgą, tak jak w przypadku świadka występującego przed sądem, ani - jak w przypadku posłańca - za pomocą formuły poświadczającej. Prawdziwość i uznanie takiego świadectwa tkwi jedynie w udziale w traumie Holokaustu poprzez bezpośrednie i niezbywalne cielesne doświadczenie przemocy. Ucieleśniona prawdziwość świadka jest w tej sytuacji jeszcze ważniejsza, niż autentyczna i staranna dbałość o szczegóły relacji, jaką stwierdzono w przypadku niejakiego Binjamina Wilkomirskiego ${ }^{21}$. Świadkowie moralni, jak pisze Jay Winter, „nie są specjalistami w zakresie jedynej prawdy.

Ibidem, s. 65.

Binjamin Wilkomirski, alias Bruno Dössecker, był autorem autobiografii Holokaustu (Bruchstücke, Frankfurt 1995), która następnie okazała się fałszerstwem. Autor, który z dużą dokładnością opisuje swoje doświadczenia z dzieciństwa w obozach śmierci, w latach 40. nigdy nie opuścił Szwajcarii. 
To, co mają do zaoferowania, jest bardzo subiektywną konstrukcją ekstremalnej sytuacji, w której się znaleźli"22 . Jako ucieleśnienie traumatycznych doświadczeń, są jednocześnie ofiarami i żywymi dowodami zbrodni, o których dają świadectwo.

Wymieniając kolejną różnicę między świadkiem jurydycznym a moralnym, Margalit nawiązuje do przemyśleń Bernharda Giesena, że świadek składa swoje świadectwo nie przed instytucją sądu, lecz na bardziej powszechnej „publicznej arenie wspólnoty moralnej”. Moralność pewnie nie jest substytutem prawa, jest uzupełnieniem prawa i odpowiedzią - i to po trosze jeszcze później, po upływie dziesięcioleci i stuleci - na nadmiar transkryminalnej zbrodni. Mając możliwość bycia wysłuchanym poza sądem, świadkowie składający świadectwo performatywnie i interaktywnie tworzą wspólnotę moralną, która nawet nie ma stałej formy ani instytucji. Powstaje jedynie dlatego, że się do niej apeluje. Dopiero poprzez włączenie osoby trzeciej (terstis), tego neutralnego adresata, powstaje owa instancja apelacyjna, która umożliwia złożenie świadectwa, wysłuchanie historii ofiary i potwierdzenie jej świadectwa ${ }^{23}$. Obecnie można zaobserwować tendencje pokazujące, że również system prawny dąży do nadania formy prawnej pytaniom moralnym. W pewnym stopniu jest to odpowiedź systemu prawnego na nacisk rosnącej publicznej świadomości moralnej. Wśród nowych ustaw znajdują się „ustawy o pamięci”, na mocy których karalne jest negowanie Holokaustu, ale także innych traumatycznych wydarzeń historycznych, takich jak wywóz i wykorzystywanie niewolników z Afryki oraz ludobójstwo Ormian. Jednakże w systemie prawnym te ustawy znacznie różnią się od innych przepisów - mają raczej symboliczne znaczenie ${ }^{24}$.

Trzecią cechą świadka moralnego, obok ucieleśnienia świadectwa i tworzenia moralnej instancji, jest według Margalita „misja prawdy”. Zakłada ona istnienie świata, w którym świadectwo ofiary, która przeżyła traumę, zostaje zignorowane, zanegowane, wyparte, zapomniane, sfałszowane lub w jakiś inny sposób zatuszowane. Misja prawdy świadka moralnego stoi w sprzeczności z potrzebą zatajenia prawdy o transkryminalnym sprawcy. Stosunek

22 J. Winter, Remembering War. The Great War Between Memory and History in the Twentieth Century, New Haven 2006, s. 271.

23 W związku z transkryminalną zbrodnią w międzyczasie powstała także instytucja prawna: Międzynarodowy Trybunał Sprawiedliwości w Hadze. Por. K. Ambos, Internationales Strafrecht, München 2006.

${ }_{24}$ Informacja od Thomasa Henne. 
jednego względem drugiego można porównać do wypukłej i wklęsłej strony soczewki - jedno wywołuje drugie na pierwszy plan. Typową intencją sprawcy jest zacieranie śladów i obrona przed winą poprzez negowanie i inne strategie uniku. Zbrodnią doskonałą jest taka zbrodnia, w której przestępca nie pozostawia śladów, i już sam fakt zbrodni jest skutecznie zatuszowany. „Któż dziś pamięta jeszcze o Ormianach?” - pytał Hitler drwiąco i zuchwale w 1939 r., w którym wywołał swoją morderczą wojnę. Jego życzeniem było, aby również „ostateczne rozwiązanie kwestii żydowskiej" nie pozostawiło żadnych śladów w pamięci ${ }^{25}$. Zapomnienie chroni sprawców i osłabia ofiary, w konsekwencji czego pamięć w postaci świadectwa stała się etycznym obowiązkiem i formą późniejszego oporu. Prawda, co wielokrotnie podkreślano, jest pierwszą „ofiarą” wojny (w znaczeniu casualty); w przypadku ludobójstwa - jest jedyną rzeczą, którą można odzyskać. Jest także istotą Truth and Reconciliation Commission, której zadaniem jest uczciwa rekonstrukcja historycznej prawdy o przebiegu traumatycznych wydarzeń po zmianie reżimu i wojnach domowych (częściowo włączając w to proces prawny) $)^{26}$.

W wypadku nazistowskiej zbrodni mordu na Żydach zapomnienie i zacieranie śladów nie stanowiły późniejszej strategii tuszowania, lecz same już były częścią tej zbrodni. Jest to strategia ukrywania i zatajania, która w wypadku sprawców przynajmniej pośrednio pozwala wywnioskować subiektywną świadomość zbrodni i winy. Güntherowi Andersowi zawdzięczamy świetne stwierdzenie, ,że wyparcie nie pojawia się dopiero po popełnieniu przestępstwa, lecz w samym działaniu, w czasie działania, nie: przed działaniem, ale wręcz jako warunek działania"27. Z tym życzeniem zapomnienia wyrażanym przez sprawcę koresponduje niczym odbicie lustrzane prośba ofiary o złożenie aktu świadectwa moralnego. Podczas gdy jedno jest nastawione na zapomnienie i zatuszowanie, celem drugiego jest zabezpieczenie śladów, pamięć i opowiadanie. Jak pisze Jay Winter, świadkowie moralni są ludźmi, „którzy zachowują uczucie wściekłości, przerażenia

25 D. Rupnow, Vernichten und Erinnern. Spuren nationalsozialistischer Gedächtnispolitik, Göttingen 2005.

A. Boraine, A Country Unmasked, Oxford 2000.

G. Anders, Wir Eichmannsöhne. Offener Brief an Klaus Eichmann, München 2002, s. $79-80$. 
i frustracji wobec kłamstw, udawania, zmiany znaczenia lub tuszowania boleśnie przez nich doświadczonej przeszłości”28.

\section{Świadectwo - na zawsze?}

Na zakończenie powróćmy jeszcze do podstawowych znaczeń słowa „świadectwo". W kontekście religijnym przybiera ono formę wyznania, w kontekście świeckim posttraumatycznej epoki po Holokauście łączy się z misją prawdy. W niektórych hebrajskich modlitewnikach akcentuje się, także typograficznie, ścisły związek między „wyznaniem” i „świadectwem”. Modlitwa Szema, z którą na ustach umiera żydowski męczennik, jest skonstruowana w taki sposób, że ostatnia litera pierwszego słowa i ostatnia litera ostatniego słowa jest wyróżniona powiększoną czcionką. Obie litery razem dają kombinację “ $e D$ ', co oznacza zarówno „świadka”, jak i „świadectwo”. Teolog Jürgen Ebach wskazał na kolejną grę literową, która jest ciekawa ze względu na podstawowe znaczenie pojęcia świadectwa ${ }^{29}$. W księdze Hioba jest miejsce, w którym słowo 'c $e D$ ' (świadectwo) jest połączone ze słowem 'c $a D$ ', mającym tę samą kombinację liter, o innej wokalizacji i oznaczającym tyle, co "na zawsze”, „na wieki” (Hi 19, 23-24). Oczywiście akt składania świadectwa ma bardzo wiele wspólnego z przyszłością.

„Świadczenie” ma też wiele wspólnego z pamięcią. Oczywiście świadczenie zawiera w sobie pamięć, czy to w obszarze prawnym, czy religijnym czy też politycznym, ale zawsze w przestrzeni publicznej. Bez publiczności nie ma świadectwa. W wypadku świadka moralnego dodatkowo nie chodzi tylko o retrospektywne wspomnienie traumatycznego doświadczenia, lecz także o inny wymiar prospektywnego zabezpieczenia tego świadectwa w przyszłości: o ustanowienie prawdy, której należy się trzymać w celu zachowania pamięci, i która ma obligatoryjny charakter, gdyż w jej świetle pamięć jawi się jako „moralna”, a zapomnienie jako „niemoralne”. Monotonia standardowej formuły „nigdy więcej!”, która towarzyszy pedagogice i retoryce Holokaustu, jest również wyrazem tej postawy, która sprawia, że pamięć o traumatycznej historii staje się świadectwem moralnym „na całą przyszłość”.

28 J. Winter, Remembering War. The Great War Between Memory and History in the Twentieth Century, New Haven 2006, s. 267. Dobrym przykładem jest sprawa Davida Irvinga kontra Deborah Lipstadt, w której misja prawdy z postępowania sądowego została przeniesiona na grunt dyskursu nauk historycznych.

29 J. Ebach, $X X X X$, [w:] H. Lowey, B. Moltmann, Erlebnis - Gedächtnis - Sinn: Authentische und Konstruierte Erinnerung, Frankfurt a.M.-New York 1996. 
„Załamanie cywilizacji” Holokaustu jawi się jako epokowy i nieodwracalny cywilizacyjny etap, o którym ludzie powinni pamiętać i który muszą przyswoić, aby nigdy więcej się nie cofnęli. Innymi słowy, w świadczeniu chodzi o pamięć w znaczeniu podtrzymywania moralnego stanu świadomości w nieokreślonej przyszłości.

Przy tym stwierdzeniu od razu nasuwa się pytanie, w jaki sposób jest zagwarantowane spisanie pamięci. Czy człowiek w ogóle sprosta temu projektowi? Już Nietzsche zadawał to pytanie: „Jak człowiek tym na wpół tępym, na wpół nierozsądnym chwilowym rozumem, tym swoistym zapominalstwem, zapamięta coś w taki sposób, aby to pozostało obecne?" ${ }^{30}$. To jest podstawowy problem każdej kulturowej mnemotechniki, której prototypem może być ostatnia wola Mojżesza. Mojżesz wypracował złożoną rytualną mnemotechnikę dla Izraelitów, która miała przetrwać ich wrodzone zapominalstwo oraz zmianę miejsca z pustyni na Ziemię Obiecaną, przy jednoczesnej zmianie epoki pokolenia doświadczeń na epokę przyszłych pokoleń. Ten program, jak wiemy, został rzeczywiście zrealizowany w judaizmie. Odpowiedź Nietzschego na to pytanie była inna - mówił on o kulturowej mnemotechnice bólu. „W pamięci zostaje jedynie to, co nie przestaje boleć”. Tę mnemotechnikę realizuje się dzisiaj tak, że izraelskie wycieczki szkolne podróżują do Auschwitz, a młodzież w wieku 17 lat staje w obliczu pamięci o własnym, fizycznym przeżyciu podróży i szokującej konfrontacji z poszczególnymi historiami cierpienia. Pamięć jest tutaj czymś więcej niż szkolną lekcją historii; oznacza wprowadzenie do dystynktywnej i ekskluzywnej wspólnoty cierpienia, definiowanej przynależnością do wspólnej traumy. Tak więc dzisiaj musimy odróżnić mnemotechnikę, realizowaną poprzez tworzenie dystynktywnej (etnicznej) grupy, od mnemotechniki realizowanej poprzez uniwersalne symbole i rytuały, których adresatami są jednostki uniwersalistycznej wspólnoty moralnej spoza różnych grup i narodów. Taka mnemotechnika wiedzie przez spisywanie, nagrywanie wideo, filmy, muzea i pomniki. Wszystkie te znaki przestankowe są świadectwami dla potomności w takim znaczeniu, że żądają zabezpieczenia prawdy w przyszłości i utrwalenia jej na stałe. Obecnie najwyraźniej daje się to wyczytać z ilości zgromadzonych w archiwach „relacji”, które powstały i powstają w obliczu szybko wykruszającego się pokolenia, które doświadczyło zdarzeń z historii. Świadectwa te $\mathrm{w}$ wielkim stylu zostały spisane, zebrane, utrwalone i zabezpieczone, aby 
w przyszłości korzystały z nich także młodsze pokolenia. Steven Spielberg, założyciel Shoah Visual History Foundation, zajmującej się filmowaniem świadectw osób, które przeżyły Holokaust, następującymi słowami opisał w pewnym wywiadzie swój projekt: „Zgromadziliśmy ponad 50 tys. relacji żyjących świadków z 57 krajów, w 31 językach. Czas trwania nagrań wyniósłby łącznie 14 lat, jest to taka ilość taśm wideo, która wystarczyłaby, aby owinąć nimi kulę ziemską" ${ }^{31}$.

"Świadectwo na zawsze" ( $\left.c e D l e^{c} a D\right)$ jest dokładnie tym, co zostało stworzone w ostatnich dwóch dziesięcioleciach, dzięki wspólnym staraniom w wielu miejscach na świecie. Ten projekt tworzenia trwałej pamięci jest tak wyraźny, że nasza epoka historyczna jest słusznie charakteryzowana poprzez „memoralizację”. Jednakże takie działania w kierunku zabezpieczenia pamięci w żadnym razie nie rozwiązują podstawowego problemu świadczenia o przeszłości. Świadectwo i świadczenie, utrwalanie i działanie performatywne, koniecznie muszą istnieć obok siebie jako wzajemnie uzupełniające się aspekty. Świadczenie jest i pozostanie działaniem, które polega na powielaniu i powtarzaniu; tutaj jeden raz się nie liczy. Zatem to od przyszłych pokoleń zależy, czy siła spisanych świadectw na stałe ukształtuje ludzkość jako moralną wspólnotę. Aby tak było, muszą one nadal szukać możliwości bycia wysłuchanym. Nie może zabraknąć świadków, którzy nadal będą świadczyli za świadków.

31 E. Lappin, Der Mann mit zwei Köpfen, Zürich 20oo, s. 5. Na temat gatunku wspomnień wideo por. A. Assmann, History, Memory, and the Genre of Testimony, „Poetics Today. International Journal for Theory and Analysis of Literature and Communication", t. 27 (2006), nr 2, s. 261-273. 